\title{
Gender differences in pharmacokinetics and pharmacodynamics of methadone substitution therapy
}

\section{OPEN ACCESS}

Edited by: Cesare Mancuso,

Catholic University School of Medicine, Italy

Reviewed by:

Giovanni Martinotti,

Università degli studi G.D'Annunzio

Chieti Pescara, Italy

Emilio Clementi,

University of Milano, Italy

${ }^{*}$ Correspondence:

Manuela Graziani,

Vittorio Erspamer School of

Physiology and Pharmacology,

Sapienza University of Rome, Piazzale

Aldo Moro 5, 00185 Rome, Italy

manuela.graziani@uniroma1.it;

Robert Nisticò,

Department of Biology, University of

Rome Tor Vergata, Via della Ricerca

Scientifica 1, 00173 Rome, Italy

robert.nistico@gmail.com

Specialty section:

This article was submitted to

Experimental Pharmacology and Drug

Discovery,

a section of the journal

Frontiers in Pharmacology

Received: 03 May 2015

Accepted: 25 May 2015

Published: 09 June 2015

Citation:

Graziani M and Nisticò R (2015)

Gender differences

in pharmacokinetics

and pharmacodynamics

of methadone substitution therapy.

Front. Pharmacol. 6:122.

doi: 10.3389/fphar.2015.00122

\author{
Manuela Graziani ${ }^{1,2 *}$ and Robert Nisticò ${ }^{3 *}$ \\ ${ }^{1}$ Vittorio Erspamer School of Physiology and Pharmacology, Sapienza University of Rome, Rome, Italy, ${ }^{2}$ Drug Addiction and \\ Clinical Pharmacology Unit, University Hospital Umberto I, Sapienza University of Rome, Rome, Italy, ${ }^{3}$ Department of \\ Biology, University of Rome Tor Vergata, Rome, Italy
}

Gender-related differences in the pharmacological effects of drug are an emerging topic. This review examines gender differences in both pharmacokinetic and pharmacodynamic aspects of methadone, a long-acting opioid agonist that is prescribed as a treatment for opioid dependence and the management of chronic pain.

Method: We performed a search in the Medline database from 1990 to 2014 in order to find published literature related to gender differences in pharmacokinetics (PK) and pharmacodynamics (PD) of methadone.

Results: None of the studies were carried out with the primary or secondary aim to identify any gender differences in the pharmacokinetic profile of methadone. Importantly; high inter-subjects variability in PK parameters was found also intra female population. The reported differences in volume of distribution could be ascribed to the physiological differences between men and women in body weight and composition, taking into account that the dose of methadone was established irrespective of body weight of patients (Peles and Adelson, 2006). On the other hand, the few studies present in literature found no gender difference in some direct pharmacodynamic parameters. Some reports have suggested that female gender is associated with an increased risk for long-QT-related cardiac arrhythmias in methadone maintenance subjects.

Conclusion: Even though it may be too simplistic to expect variability only in one parameter to explain inter-individual variation in methadone response, we believe that a better knowledge of gender-related differences might have significant implications for better outcomes in opioid dependence substitution therapy in women.

Keywords: gender differences, pharmacokinetics, pharmacodynamics, methadone treatment, toxicology

\section{Introduction}

The most recent statistical data in Europe (EMCDDA, 2014) indicate that females represent roughly one in four drug users entering drug treatment and one in five deaths directly related to drug use. However, although drug abuse is actually more common among men than women, a progressively higher percentage of women in the world abuse both legal and/or illegal psychoactive 
drugs (Greenfield et al., 2003; Becker and Hu, 2008), making studies regarding gender differences in drug abuse extremely relevant. Gender differences are referred to all phases of natural history of drug abuse, i.e., initiation (Green et al., 2002; Becker and $\mathrm{Hu}, 2008$; Roy et al., 2011; Shand et al., 2011), escalation (Hernandez-Avila et al., 2004), relapse, and treatment retention (Lynch et al., 2002; Greenfield et al., 2007; Niv and Hser, 2007; Kennedy et al., 2013), as well as to adverse effects (Gupta et al., 2007), psychiatric comorbidity (Edokpolo et al., 2010; Sara et al., 2013), and the class of drug of abuse (Simoni-Wastila et al., 2004; Tetrault et al., 2008). Possible factors that could contribute to gender differences are related to $\mathrm{PK}$ and $\mathrm{PD}$ variables.

Heroin abuse, despite the large increase in the 1990s, decreased in the last decade, in spite of the ascending trends in designer drugs consumers (Schifano et al., 2005), and behavioral addictions (Martinotti et al., 2014). Unfortunately, more recent data (NSDUH, 2010) indicate that in US the number of heroin initiates was significantly higher than the average annual number between 2002 and 2008. Recent data from the National Institute of Drug Abuse (NIDA, 2014) highlight the unexpected association of prescription pain reliever abuse and heroin, indicating the possible transition of experimenting with non-medical prescription pain relievers through heroin abuse. Data from 24 European countries also show an overall decrease in the number of heroin clients. The number of first-time heroin clients increased from 2005 to 2007 and then decreased in 2011 (EMCDDA, 2014). In line with data on population of both genders, the 2007 US National Survey on Drug Use and Health indicates that the rate of current heroin use decreased between 2006 and 2007 from 0.06 to $0.02 \%$ per cent among females aged 12 or older.

Currently methadone (M) is the most commonly prescribed replacement therapy for opioid dependence (only in the US $40 \%$ are female patients). In fact, recent data (EMCDDA, 2014) indicate that in Europe buprenorphine is prescribed to about $20 \%$ of the substitution treatment opioid users, whereas almost 734.000 opioid users received substitution treatment in Europe during 2012.

Although more than 15 years ago the FDA recommended women may be increasingly included in clinical trials (U.S. Food and Drug Administration, 1993), to date, gender difference in pharmacological response to opioids is scarcely investigated and only few clinical studies on opioid drugs (such as heroin, opioid pain relievers, and the opioids in dependence treatment $\mathrm{M}$ and buprenorphine) include gender as a factor. Increasing the knowledge of pharmacological aspects related to opioid substitution therapy drugs with relevance to female and male difference is essential for a better understanding of factors that influence opioid use among women, and might contribute to the identification and clinical use of gender-tailored therapy.

\section{Aim of the Work}

The goal of this review is to supply a selective summary of the literature analyzing pharmacokinetic and pharmacodynamic aspects of $\mathrm{M}$ with specific focus on data obtained in women.
We have also considered a limited number of studies including only male subjects, with the aim to hypothesize some gender differences, and also to underscore paucity of data.

\section{Methods}

We reviewed the literature and searched for published articles related to gender differences in opioids pharmacokinetics (PK) and pharmacodynamics (PD). The MEDLINE database was examined from 1990 to 2014, using PubMed. Main key words used were: methadone, opioid, substitution therapy, pharmacology, PK, PD, sex/gender difference, individually, and variously paired.

\section{Methadone: PK and PD}

Knowledge on $\mathrm{PK}$ and $\mathrm{PD}$ of $\mathrm{M}$, in relation to different demographic characteristics (age, sex, pregnancy), pathophysiology of patients (renal impairment), and also drug interactions may contribute to the understanding of the well known individual variability in response to $\mathrm{M}$ treatment; this may in turn lead to an optimization of $M$ therapy. Nevertheless and despite the fact that women are more susceptible to some of the adverse effects of $\mathrm{M}$, such as the lengthening of the QT interval (Pearson and Woosley, 2005), the studies to investigate $M$ treatment were carried out mainly on samples from the male population (Chopra et al., 2008).

\section{Pharmacokinetics}

Available literature between 1990 and 2014 related to the PK of $\mathrm{M}$ with particular reference to any gender difference is listed in Table 1.

\section{Absorption and Distribution}

As noted, $\mathrm{M}$ is characterized by high lipid solubility and protein binding (Foster et al., 2000; Ferrari et al., 2004; Vazquez et al., 2006). A study conducted to investigate the steady-state PK of (R)- and (S)-methadone in an $M$ maintenance population ( $N=18,39 \%$ women) showed no gender-related effect on plasma concentration-time profiles after a multiple dosing regimen for either (R)-methadone or (S)-methadone, neither on $\alpha 1$ acid glycoprotein plasma concentration. Similarly, no effect of gender difference on initial Volume of distribution (Vd) in a sample of 35 opiate users ( $\mathrm{M}$ single dose: $N=23 ; 26 \%$ women; $\mathrm{M}$ multiple doses: $N=29 ; 45 \%$ women was found (Rostami-Hodjegan et al., 1999); however, in this study, since $\mathrm{M}$ dose was in a range of 5-80 $\mathrm{mg}$ and plasma concentrations were assessed and normalized to the dose of $70 \mathrm{mg}$ using a population-based pharmacokinetic approach, gender effect on dose-concentration relationship could not be evaluated. When higher values of central Vd were found in female users (RostamiHodjegan et al., 1999), this parameter was directly related to sex differences in body weight. Accordingly, Wolff et al. (1997) in a sample of 21 males e 14 females reported that the $\mathrm{Vd}$ of $\mathrm{M}$ was affected by weight, but not by gender. On the 
TABLE 1 | Pharmacokinetics (PK) studies on methadone (M).

\begin{tabular}{|c|c|c|c|c|c|c|}
\hline Reference & $\begin{array}{l}\text { Subjects } N \\
\text { (\% female) }\end{array}$ & $\begin{array}{l}\text { Subjects } \\
\text { category* }\end{array}$ & Dosage regimen & $\begin{array}{l}\text { Dose } \\
\text { range }(\mathrm{mg})\end{array}$ & $\begin{array}{l}\text { Biologic fluid of } \\
\text { determination }\end{array}$ & Sex difference (female) \\
\hline Bart et al. (2014) & $206(39)$ & 1 & Multiple dosing & $35-120$ & Plasma & Sex data not published separately \\
\hline Shiran et al. (2009) & $88(24)$ & 1 & Multiple dosing & $15-130$ & Plasma & $\begin{array}{l}=(\mathrm{R})-,(\mathrm{S})-\text { and }(\mathrm{R})-(\mathrm{S})-\mathrm{M} \text { plasma } \\
\mathrm{C}^{* *} ;=\mathrm{M} \text { clearance }\end{array}$ \\
\hline Fredheim et al. (2007) & $12(42)$ & $\|$ & Multiple dosing & $20-85$ & Plasma & $\begin{array}{l}\text { Sex data on } \mathrm{M} \text { and EDDP*** } \\
\text { plasma } \mathrm{C} \text { not published } \\
\text { separately }\end{array}$ \\
\hline Hanna et al. (2005) & $6(1)$ & 1 & $\begin{array}{l}\text { Multiple dosing } \\
\text { (no dose change greater } \\
\text { than } 15 \text { mg during the last } \\
6 \text { months) }\end{array}$ & $20-170$ & Plasma & Sex data not published separately \\
\hline Foster et al. (2004) & $59(39)$ & 1 & $\begin{array}{l}\text { Multiple dosing } \\
\text { (no dose change for at least } \\
2 \text { months) }\end{array}$ & $7.5-150$ & Plasma & $>V d^{* * * *}$ \\
\hline Preston et al. (2003) & $27(3)$ & I & $\begin{array}{l}\text { Multiple dosing } \\
\text { (no dose change for at least } \\
1 \text { week) }\end{array}$ & $35-80$ & Urine & $>$ EDDP C \\
\hline Boulton et al. (2001) & $8(100)$ & III & Single dose & $0.2 \mathrm{mg} / \mathrm{Kg}$ & Plasma and urine & $\begin{array}{l}\text { High inter-subjects variability in } \\
\text { PK and PD parameters }\end{array}$ \\
\hline Wolff et al. (2000) & $35(38)$ & 1 & Single dose & $5-80$ & Plasma & $\begin{array}{l}\text { Difference in Vd not specified; } \\
=\mathrm{M} \text { clearance }\end{array}$ \\
\hline Foster et al. (2000) & $18(12)$ & 1 & $\begin{array}{l}\text { Multiple dosing } \\
\text { (no dose change for at least } \\
2 \text { months) }\end{array}$ & $7.5-130$ & Plasma & $\begin{array}{l}=\text { unbound fractions for }(\mathrm{R})-\mathrm{M} ; \\
=\text { a1-acid glycoprotein } \mathrm{C} ; \\
=\text { plasma C-time profiles for } \\
\text { either }(\mathrm{R}) \text { - or }(\mathrm{S})-\mathrm{M} ;\end{array}$ \\
\hline $\begin{array}{l}\text { Rostami-Hodjegan } \\
\text { et al. (1999) }\end{array}$ & $\begin{array}{l}17(6) \\
19(13)\end{array}$ & $\begin{array}{l}\| \\
1\end{array}$ & $\begin{array}{l}\text { Single dose } \\
\text { Multiple dosing (Days 6-37) }\end{array}$ & $\begin{array}{l}5-80 \\
5-80\end{array}$ & Plasma & $\begin{array}{l}=\mathrm{Vd} \\
=\text { Clearance }\end{array}$ \\
\hline Preston et al. (2003) & $27(3)$ & I & $\begin{array}{l}\text { Multiple dosing } \\
\text { (no dose change for at least } \\
1 \text { week) }\end{array}$ & $35-80$ & Urine & $\begin{array}{l}>\text { Creatinine-corrected EDDP C } \\
>\text { non-significantly higher M C } \\
=\text { EDDP/M ratio }\end{array}$ \\
\hline Eap et al. (1996) & $22(4.4)$ & 1 & $\begin{array}{l}\text { Multiple dosing (R)-M } \\
\text { and subsequently (R, S)-M }\end{array}$ & $120-160$ & Plasma & Sex data not published separately \\
\hline de Vos et al. (1995) & 20 & $\|$ & Multiple dosing & $10-225$ & Plasma & $<\mathrm{M}$ clearance \\
\hline
\end{tabular}

contrary, Foster et al. (2004), identified gender and plasma a1acid glycoprotein concentration as significant determinants of apparent $\mathrm{Vd}$ of the central compartment $(\mathrm{Vc} / \mathrm{F})$. These data are consistent with those observed by Rostami-Hodjegan et al. (1999), which report that gender and weight (factors affecting body composition) were the two main covariates accounting for $33 \%$ of the inter-individual variability in $\mathrm{M} \mathrm{Vd}$ at the steadystate.

\section{Metabolism}

$\mathrm{M}$ biotransformation is largely mediated by CYP3A4 and CYP2D6 (Eap et al., 2002), although CYP2B6 (Dennis et al., 2014), CYP2C9, and CYP2C19 also appear to be involved, but to a much lesser degree (Foster et al., 1999).

\section{CYP3A4}

CYP3A4 is responsible for $\mathrm{M}$ biotransformation in the major metabolite 2-ethylidene-1,5-dimethyl-3,3-diphenylpyrrolidine (EDDP; Eap et al., 2002). Studies (Charlier et al., 2001; Eap et al., 2002) aimed to identify the proper daily dose found a poor correlation between $M$ doses and $M$ serum concentrations. In another study (Boulton et al., 2001), performed on eight healthy drug-free women, the authors showed a correlation between urinary cortisol, area under the curve, and elimination of EDDP (a metabolite of M). Recently, Shiran et al. (2009) in a study conducted in a sample of 88 subjects ( 30 females) found that CYP3A4 activity has a modest influence on $\mathrm{M}$ disposition.

The discrepancy between these results could be affected by several factors: conditions of concentration at steady state vs. single dose, patients in methadone maintenance therapy (MMT) vs. volunteers not taking chronic opiates.

To date inter-individual variations in the expression of CYP3A4 are thought to be the main factor responsible for interindividual variability in $\mathrm{M}$ response ( $\mathrm{Li}$ et al., 2008): indeed, genetic polymorphism is considered the cause of high variability of $\mathrm{M}$ blood concentrations for a given dose.

Moreover, CYP3A4 seems to be the main isoenzyme of the CYP family showing significant sex differences, since 
its expression in women is 1.5-2 times higher than in men (Wolbold et al., 2003): the underlying mechanism is presumably type transcriptional, linked to the mRNA. Notably, CYP3A4 expression in the liver is controlled also by dynamic interactions with transcription factors such as expression of the ABCB1 (multidrug resistance 1 [MDR1]) gene encoding the P-glycoprotein (P-gp) efflux transporter (Schuetz et al., 2000). Since hepatic P-gp protein expression is twofold lower in women than in men (Schuetz et al., 1995) this could increase the intra-hepatic concentration of $M$ and in turn its more extensive metabolism. In this regard, pharmacogenetic studies indicate that it is important to stratify by gender when examining genotype/phenotype associations, especially for genes, such as CYP3A4, which are differently expressed between genders (Lamba et al., 2003, 2006).

\section{CYP2D6}

CYP2D6 contributes only to a small extent to the formation of EDDP (Eap et al., 2002). It exhibits a high polymorphism: to date, over 75 different alleles have been identified (Borobia et al., 2009), differently expressed among ethnic groups (Xie et al., 2001).

Clinical data regarding gender differences in the activity of CYP2D6 are controversial. Some authors found no differences among males and females, including poor metabolizers subjects (Kashuba et al., 1998; Tamminga et al., 2001). Conversely, Labbé et al. (2000) found in a sample of extensive metabolizers subjects, that the metabolism of CYP2D6 substrate dextromethorphan, is higher in women than in men, as confirmed by Hägg et al. (2001).

Methadone maintenance therapy patients Shiran et al. (2003) observed a lower activity of CYP2D6 (rated metabolic ratio of dextromethorphan) in women; the results of this study revealed the presence of a substantial genotype/phenotype discrepancy in MMT patients, consistent with inhibition of CYP2D6. Authors speculate that the chronic intake of $\mathrm{M}$ might induce inhibition of CYP2D6, similarly, to the one observed in in vitro conditions (Wu et al., 1993). This hypothesis could explain, according to the authors, that the difference in activity observed in both genders may result from possible differences between themselves in the plasma concentration of $\mathrm{M}$ administered at the same dose. In any case, in a more recent study involving 88 subjects (including 30 women), Shiran et al. (2009) evaluated the possible influences of the activity of CYP2D6, 1A2, and 3A4 on the availability of $M$, reporting that gender did not have a significant influence, along with other covariates such as CYP activity, weight, and age, neither on the plasma concentration of $M$ nor on its clearance.

\section{Excretion}

$\mathrm{M}$ undertakes hepatic metabolism and renal excretion (Garrido and Trocóniz, 1999). With respect to its hepatic elimination, $\mathrm{M}$ has a restricted clearance or a low extraction ratio, while, as a consequence of its chemical properties, urine $\mathrm{pH}$ has been shown to influence the excretion of $\mathrm{M}$ (Inturrisi et al., 1987). To our knowledge, there are no studies that have shown gender differences in the excretion of $\mathrm{M}$; however, it is useful to point out that recently Poggio et al. (2009) observed that females had slightly but significantly higher glomerular filtration rate (measured by $125 \mathrm{I}$-iothalamate clearances) than males after adjustment for body surface area, but there were no differences due to race. Instead, Berg (2006) found no difference in glomerular filtration rate by clearance of para-aminohippuric acid (PAH) between males and females, in a total of 122 potential kidney donors (62 females).

To summarize, none of the studies was carried out with the primary or secondary aim to identify any gender differences in the pharmacokinetic profile of M. Importantly, high intersubjects variability in $\mathrm{PK}$ parameters was found also intra female population (Boulton et al., 2001) Anyway, when women are included in clinical studies and sex data were analyzed separately some significant differences were detected.

The physiological differences between men and women in body weight and composition (per cent of fat, plasma volume, and organ blood flow) could be evoked to explain difference in $\mathrm{Vd}$, taking into account dose $\mathrm{M}$ is established irrespective of body weight of patients (Peles and Adelson, 2006). It can be hypothesized that, in turn, changes in $\mathrm{Vd}$ may in turn affect both the levels of plasma concentration and the half-life, with consequences on the effect of drugs in terms of onset of action and duration of effects.

\section{Pharmacodynamics}

Clinical studies on M PK/PD relationship are listed in Table 2. None of these studies has been conducted to primarily identify a possible difference in M PD parameters in women compared to men; in most of the studies gender data are not analyzed separately. In a study conducted by Hiltunen et al. (1999), no influence of gender was found on the interaction between l-M plasma concentrations and subjective opiate withdrawal scale (SOWS) of "negative" (irritability, disorientation, remorse, sadness, and low psychomotor speed), and "positive" effects (feelings of alertness, calmness, patience, relaxation, cheerfulness, carefreeness, and clear-thinking). Peles and Adelson (2006) comparing gender outcome among 470 MMT patients $(28 \%$ women) found no gender differences in treatment retention, stop in opiate abuse, and decrease in cocaine abuse. The average $M$ dose was almost the same between men and women $(131.1 \pm 54.8 ; 132.3 \pm 49.5 \mathrm{mg})$.

On the contrary in another study (Pérez de Los Cobos et al., 2005) conducted on 169 patients (33\% women) to evaluate satisfaction with treatment (dose adjustment, participation in dosage regulation) it was found that female patients had more positive opinions and a better satisfaction than males about $\mathrm{M}$ as a medication. Accordingly, some authors (Green, 2006; Greenfield et al., 2007) observed that males were more expected to drop out of outpatient drug-free programs, whereas females were more likely to be considered in the low-retention group for outpatient M treatment (Simpson et al., 1997). In a more recent study aimed to ascertain gender and $M$ maintenance dose influence on naloxone response in volunteers, a significant difference in mean $\mathrm{M}$ doses was observed between males and females (when body weight was considered; Chopra et al., 2008). These results indicate that women on lower $\mathrm{M}$ maintenance doses might be very sensitive to the dysphoric effects of naloxone-induced opiate withdrawal. 
TABLE 2 | Methadone (M) PK/PD relationship studies.

\begin{tabular}{|c|c|c|c|c|c|c|}
\hline Reference & $\begin{array}{l}\text { Subjects } \\
\mathrm{N} \text { (\% female) }\end{array}$ & $\begin{array}{l}\text { Subjects } \\
\text { Category* }\end{array}$ & $\begin{array}{l}\text { Dosage } \\
\text { regimen }\end{array}$ & $\begin{array}{l}\text { Dose range } \\
\text { (mg) }\end{array}$ & PD effect & $\begin{array}{l}\text { Findings/ } \\
\text { Comments }\end{array}$ \\
\hline Hanna et al. (2005) & $6(16.6)$ & I & Repeated dose & 20-170 mg/die & $\begin{array}{l}\text { Antinociception, mood } \\
\text { disturbance, respiration rate, } \\
\text { pupil size, withdrawal. }\end{array}$ & $\begin{array}{l}\text { Highly significant differences in the } \\
\text { between- to within-subject } \\
\text { variability. Small subjects number }\end{array}$ \\
\hline $\begin{array}{l}\text { Maremmani et al. } \\
\text { (2005) }\end{array}$ & $83(24)$ & 1 & Repeated dose & $10-600$ mg/die & QTc prolongation & $\begin{array}{l}\text { No correlation between QTc values } \\
\text { and M doses; no gender } \\
\text { differences in QTc values }\end{array}$ \\
\hline $\begin{array}{l}\text { Pearson and } \\
\text { Woosley (2005) }\end{array}$ & $58(59)$ & I & Repeated dose & 29-1680 mg/die & QTc prolongation and/or TdP & $\begin{array}{l}\text { Female gender as risk factor; QT } \\
\text { prolongation at therapeutic dose }\end{array}$ \\
\hline Pérez de Los & $165(23)$ & 1 & Repeated dose & & & \\
\hline Cobos et al. (2005) & & & & $12-150 \mathrm{mg} / \mathrm{die}$ & Patient M therapy satisfation & Female gender more satisfied \\
\hline Fisher et al. (2004) & $6(50)$ & $\|$ & Repeated dose & $1-4 \times 1-25 \mathrm{mg} / \mathrm{die}$ & Antinociception & $\begin{array}{l}\text { Patients' heterogeneous condition; } \\
\text { data not analyzed by gender; small } \\
\text { subjects number }\end{array}$ \\
\hline Mitchell et al. (2004) & $55(38)$ & I & Repeated dose & 7.5-300 mg/die & $\begin{array}{l}\text { Mood disturbance, respiration } \\
\text { rate, pupil size, heart rate, } \\
\text { blood pressure, withdrawal. }\end{array}$ & $\begin{array}{l}\text { Gender data not published } \\
\text { separately; M AUC** not related to } \\
\text { PD responses, except for mood } \\
\text { disturbance and heart rate }\end{array}$ \\
\hline Dyer et al. (2001) & $18(39)$ & I & Repeated dose & 7.5-130 mg/die & Mood disturbance & $\begin{array}{l}\text { Gender data not published } \\
\text { separately; M plasma } \\
\text { concentration inversely related to } \\
\text { mood disturbance }\end{array}$ \\
\hline $\begin{array}{l}\text { Boulton et al. } \\
\text { (2001) }\end{array}$ & $8(100)$ & III & Single dose & $0.2 \mathrm{mg} / \mathrm{Kg}$ & Pupil diameter & Large inter-subject variability \\
\hline Dyer et al. (1999) & $18(39)$ & I & Repeated dose & 7.5-130 mg/die & $\begin{array}{l}\text { Withdrawal severity, Pain } \\
\text { threshold, Pupil diameter, } \\
\text { Respiratory rate }\end{array}$ & $\begin{array}{l}\text { No differences between holders } \\
\text { and non-holders with respect to } \\
\text { gender }\end{array}$ \\
\hline $\begin{array}{l}\text { Gourevitch et al. } \\
\text { (1999) }\end{array}$ & $18(56)$ & I & Repeated dose & 30-100 mg/die & Withdrawal & $\begin{array}{l}\text { Gender data not published } \\
\text { separately; no correlation between } \\
\text { self-reported symptoms of } \\
\text { withdrawal and trough plasma M } \\
\text { levels. }\end{array}$ \\
\hline $\begin{array}{l}\text { Hiltunen et al. } \\
\text { (1999) }\end{array}$ & $50(24)$ & 1 & Repeated dose & 35-140 mg/die & $\begin{array}{l}\text { Objective and subjective } \\
\text { withdrawal scale in relation to } \\
\text { plasma } \mathrm{M} \mathrm{C}^{* * *}\end{array}$ & $\begin{array}{l}\text { No gender differences on the } \\
\text { interaction between I-M plasma } \\
\text { concentrations and "negative" as } \\
\text { well as of "positive" M effects }\end{array}$ \\
\hline Inturrisi et al. (1990) & $15(27)$ & $\|$ & $\begin{array}{l}\text { i.v. infusion } \\
\text { (180-270 min) }\end{array}$ & $\begin{array}{l}\text { 20-25 mg/hour } \\
\text { (loading dose) }\end{array}$ & $\begin{array}{l}\text { Relationship between plasma } \\
\text { M C and PD effects (analgesia } \\
\text { and sedation) }\end{array}$ & Sex data not published separately \\
\hline
\end{tabular}

$* I=$ Methadone maintenance treatment, $I I=$ Patients with cancer-related pain, $I I I=$ healthy subjects.

** $=$ Area under the curve.

$* * *=$ Concentration.

It should, however, be noted that no pharmacodynamic parameters were directly analyzed. Some studies have shown a difference in $\mu$-opioid binding between males and females. Smith et al. (1998), using positron emission tomography (PET), observed a higher $\mu$-opioid binding in women in a number of cortical and subcortical areas. Furthermore, gonadal steroid hormones such as estrogenic states can influence $\mu$-opioid receptor density (related to opioid relative efficacy) and signal transduction (Smith et al., 1998). More recently Smith et al. (2006) have demonstrated that a high-estrogen state is related to area-specific increases in $\mu$-opioid receptor availability, while during the low estrogenic conditions significant reduction in endogenous opioid tone was observed at the level of thalamus, nucleus accumbens, and amygdala. Age is another factor that can contribute to $\mu$-receptor occupancy. In fact, in postmenopausal women the in vivo $\mu$-opioid binding decreases to levels below those of men (Zubieta et al., 1999).

Some studies (Drici and Clément, 2001; Pearson and Woosley, 2005), although not equivocally (Maremmani et al., 2005), have suggested that female gender is associated with higher risk for long-QT (LQT)-dependent cardiac arrhythmias in MMT subjects. Reports to the FDA spontaneous reporting system (however, considered an underestimation of the total number of events) indicate that in a total of 5503 reports of adverse events associated with $\mathrm{M}, 1.07 \%$ noted the occurrence of QT prolongation and $\mathrm{TdP}$, and that $59 \%$ were females. Importantly, the dosages for $29 \%$ of the cases were within the recommended range for $\mathrm{M}$ maintenance treatment $(60-100 \mathrm{mg} /$ day), indicating that pharmacodynamic variables, not pharmacokinetic, might explain this cardiac effect. 
Among the possible factors that can contribute to $\mathrm{M}$ cardiac toxicity, there may be physiological differences in cardiac conduction between genders: the baseline QTc of the post puberty female is longer than that of males (Abi-Gerges et al., 2004), suggesting that sex steroid hormones are implicated in modulating cardiac repolarization; drugs like $\mathrm{M}$ blocking cardiac voltage gated potassium channels, particularly the rapid component (IKr) of the delayed rectifier potassium current (IK), may induce a prolongation of the QT interval (Drici and Clément, 2001). In contrast, in a study (Maremmani et al., 2005) conducted to assess the incidence of abnormal QTc interval values in a population of subjects (20 females, 63 males) on a long-term MMT (60-100 mg/die), gender differences in the recorded QTc values were found not statistically significant. It should be noted, however, that the number of women enrolled in the sample was not very high, as it has not been clarified whether the average $\mathrm{M}$ dose was lower in women than in men.

In summary, considering the above mentioned inter women variability, the few studies present in literature found no gender difference in some direct pharmacodynamic parameters (withdrawal severity, pain threshold, pupil diameter, and

\section{References}

Abi-Gerges, N., Philp, K., Pollard, C., Wakefield, I., Hammond, T. G., and Valentin, J. P. (2004). Sex differences in ventricular repolarization: from cardiac electrophysiology to Torsades de Pointes. Fundam. Clin. Pharmacol. 18, 139-151. doi: 10.1111/j.1472-8206.2004.00230.x

Bart, G., Lenz, S., Straka, R. J., and Brundage, R. C. (2014). Ethnic and genetic factors in methadone pharmacokinetics: a population pharmacokinetic study. Drug. Alcohol Depend. 145, 185-193. doi: 10.1016/j.drugalcdep.2014. 10.014

Becker, J. B., and Hu, M. (2008). Sex differences in drug abuse. Front. Neuroendocrinol. 29:47. doi: 10.1016/j.yfrne.2007.07.003

Berg, U. B. (2006). Differences in decline in GFR with age between males and females. Reference data on clearances of inulin and PAH in potential kidney donors. Nephrol. Dial. Transplant. 21, 2577-2582. doi: 10.1093/ndt/gfl227

Borobia, A. M., Novalbos, J., Guerra-López, P., López-Rodríguez, R., Tabares, B., Rodríguez, V., et al. (2009). Influence of sex and CYP2D6 genotype on mirtazapine disposition, evaluated in Spanish healthy volunteers. Pharmacol. Res. 59, 393-398. doi: 10.1016/j.phrs.2009.02.006

Boulton, D. W., Arnaud, P., and DeVane, C. L. (2001). Pharmacokinetics and pharmacodynamics of methadone enantiomers after a single oral dose of racemate. Clin. Pharmacol. Ther. 70, 48-57. doi: 10.1067/mcp.2001.116793

Charlier, C., Dessalles, M. C., and Plomteux, G. (2001). Methadone maintenance treatment: is it possible to adapt the daily doses to the metabolic activity of the patient? Ther. Drug. Monit. 23, 1-3. doi: 10.1097/00007691-200102000-00001

Chopra, M. P., Feldman, Z., Mancino, M. J., and Oliveto, A. (2008). Sex and opioid maintenance dose influence response to naloxone in opioid-dependent humans: a retrospective analysis. Pharmacol. Biochem. Behav. 90, 787-796. doi: 10.1016/j.pbb.2008.05.023

de Vos, J. W., Geerlings, P. J., van den Brink, W., Ufkes, J. G., and van Wilgenburg, H. (1995). Pharmacokinetics of methadone and its primary metabolite in 20 opiate addicts. Eur. J. Clin. Pharmacol. 48, 361-366. doi: 10.1007/BF00194951

Dennis, B. B., Bawor, M., Thabane, L., Sohani, Z., and Samaan, Z. (2014). Impact of $\mathrm{ABCB} 1$ and CYP2B6 genetic polymorphisms on methadone metabolism, dose and treatment response in patients with opioid addiction: a systematic review and meta-analysis. PLoS ONE 29:e86114. doi: 10.1371/journal.pone.0086114

Drici, M. D., and Clément, N. (2001). Is gender a risk factor for adverse drug reactions? The example of drug-induced long QT syndrome. Drug Saf. 24, 575-585. doi: 10.2165/00002018-200124080-00002 respiratory rate, as well as in the interaction between 1-M plasma concentration and its "negative"/"positive" effects. However, there is no consensus in the literature about gender differences in treatment satisfaction and retention in $M$ substitution therapy. On the other hand, there is clear evidence of women's vulnerability to $M$ cardiac adverse effects that may be related to gender-related physiological differences in cardiac conduction.

\section{Conclusion}

To date, data available on M PK and PD focuses primarily on male subjects. Little is known about women or how the genders compare. We hope that future studies will determine the exact contribution of the gender factor to the inter-individual variation of the pharmacology of $\mathrm{M}$ in patients. Even though it may be too simplistic to expect variability only in one parameter to explain inter-individual variation in $\mathrm{M}$ response, we believe that a better understanding of gender-related differences might have important implications for a better outcome in opioid dependence substitution therapy in women.

Dyer, K. R., Foster, D. J., White, J. M., Somogyi, A. A., Menelaou, A., and Bochner, F. (1999). Steady-state pharmacokinetics and pharmacodynamics in methadone maintenance patients: comparison of those who do and do not experience withdrawal and concentration-effect relationships. Clin. Pharmacol. Ther. 65, 685-694. doi: 10.1016/S0009-9236(99) 90090-5

Dyer, K. R., White, J. M., Foster, D. J., Bochner, F., Menelaou, A., and Somogyi, A. A. (2001). The relationship between mood state and plasma methadone concentration in maintenance patients. J. Clin. Psychopharmacol. 21, 78-84. doi: 10.1097/00004714-200102000-00014

Eap, C. B., Buclin, T., and Baumann, P. (2002). Interindividual variability of the clinical pharmacokinetics of methadone: implications for the treatment of opioid dependence. Clin. Pharmacokinet. 41, 1153-1193. doi: 10.2165/00003088-200241140-00003

Eap, C. B., Finkbeiner, T., Gastpar, M., Scherbaum, N., Powell, K., and Baumann, P. (1996). Replacement of (R)-methadone by a double dose of (R,S)-methadone in addicts: interindividual variability of the $(\mathrm{R}) /(\mathrm{S})$ ratios and evidence of adaptive changes in methadone pharmacokinetics. Eur. J. Clin. Pharmacol. 50, 385-389. doi: $10.1007 / \mathrm{s} 002280050128$

Edokpolo, O., James, P., Kearns, C., Campbell, A., and Smyth, B. P. (2010). Gender differences in psychiatric symptomatology in adolescents attending a community drug and alcohol treatment program. J. Psychoactive Drugs 42, 31-36. doi: 10.1080/02791072.2010.10399783

EMCDDA. (2014). European Monitoring Centre for Drugs and Drug Addiction, Lisbon. Available at: http://www.emcdda.europa.eu/edr2014

Ferrari, A., Coccia, C. P., Bertolini, A., and Sternieri, E. (2004). Methadonemetabolism, pharmacokinetics and interactions. Pharmacol. Res. 50, 551-559. doi: 10.1016/j.phrs.2004.05.002

Fisher, K., Stiles, C., and Hagen, N. A. (2004). Characterization of the early pharmacodynamic profile of oral methadone for cancer-related breakthrough pain: a pilot study. J. Pain Symptom Manage. 28, 619-625. doi: 10.1016/j.jpainsymman.2004.03.003

Foster, D. J., Somogyi, A. A., and Bochner, F. (1999). Methadone N-demethylation in human liver microsomes: lack of stereoselectivity and involvement of CYP3A4. Br. J. Clin. Pharmacol. 47, 403-412. doi: 10.1046/j.13652125.1999.00921.x

Foster, D. J., Somogyi, A. A., Dyer, K. R., White, J. M., and Bochner, F. (2000). Steady-state pharmacokinetics of (R)- and (S)-methadone in methadone maintenance patients. Br. J. Clin. Pharmacol. 50, 427-440. doi: 10.1046/j.13652125.2000.00272.x 
Foster, D. J., Somogyi, A. A., White, J. M., and Bochner, F. (2004). Population pharmacokinetics of (R)-, (S)- and rac-methadone in methadone maintenance patients. Br. J. Clin. Pharmacol. 57, 742-755. doi: 10.1111/j.13652125.2004.02079.x

Fredheim, O. M., Borchgrevink, P. C., Klepstad, P., Kaasa, S., and Dale, O. (2007). Long term methadone for chronic pain: a pilot study of pharmacokinetic aspects. Eur. J. Pain. 11, 599-604. doi: 10.1016/j.ejpain.2006.09.006

Garrido, M. J., and Trocóniz, I. F. (1999). Methadone: a review of its pharmacokinetic/pharmacodynamic properties. J. Pharmacol. Toxicol. Methods 42, 61-66. doi: 10.1016/S1056-8719(00)00043-5

Gourevitch, M. N., Hartel, D., Tenore, P., Freeman, K., Marion, I., Hecht, J., et al. (1999). Three oral formulations of methadone. A clinical and pharmacodynamic comparison. J. Subst. Abuse Treat. 17, 237-241. doi: 10.1016/S0740-5472(99)00008-2

Green, C. A. (2006). Gender and use of substance abuse treatment services. Alcohol Res. Health 29, 55-62.

Green, C. A., Polen, M. R., Dickinson, D. M., Lynch, F. L., and Bennett, M. D. (2002). Gender differences in predictors of initiation, retention, and completion in an HMO-based substance abuse treatment program. J. Subst. Abuse Treat. 23, 285-295. doi: 10.1016/S0740-5472(02)00278-7

Greenfield, S. F., Brooks, A. J., Gordon, S. M., Green, C. A., Kropp, F., McHugh, R. K., et al. (2007). Substance abuse treatment entry, retention, and outcome in women: a review of the literature. Drug. Alcohol Depend. 86, 1-21. doi: 10.1016/j.drugalcdep.2006.05.012

Greenfield, S. F., Manwani, S. G., and Nargiso, J. E. (2003). Epidemiology of substance use disorders in women. Obstet. Gynecol. Clin. North Am. 30, 413-446. doi: 10.1016/S0889-8545(03)00072-X

Gupta, A., Lawrence, A. T., Krishnan, K., Kavinsky, C. J., and Trohman, R. G. (2007). Current concepts in the mechanisms and management of drug-induced QT prolongation and torsade de pointes. Am. Heart J. 153, 891-899. doi: 10.1016/j.ahj.2007.01.040

Hägg, S., Spigset, O., and Dahlqvist, R. (2001). Influence of gender and oral contraceptives on CYP2D6 and CYP2C19 activity in healthy volunteers. Br. J. Clin. Pharmacol. 51, 169-173. doi: 10.1111/j.1365-2125.2001. 01328.x

Hanna, J., Foster, D. J., Salter, A., Somogyi, A. A., White, J. M., and Bochner, F. (2005). Within- and between- subject variability in methadone pharmacokinetics and pharmacodynamics in methadone maintenance subjects. Br. J. Clin. Pharmacol. 60, 404-413. doi: 10.1111/j.1365-2125.2005. 02464.x

Hernandez-Avila, C. A., Rounsaville, B. J., and Kranzler, H. R. (2004). Opioid-, cannabis- and alcohol-dependent women show more rapid progression to substance abuse treatment. Drug Alcohol Depend. 74, 265-272. doi: 10.1016/j.drugalcdep.2004.02.001

Hiltunen, A. J., Beck, O., Hjemdahl, P., Liljeberg, P., Almström, U., Brodin, K., et al. (1999). Rated well-being in relation to plasma concentrations of 1- and d-methadone in satisfied and dissatisfied patients on methadone maintenance treatment. Psychopharmacology (Berl). 143, 385-393. doi: 10.1007/s002130050963

Inturrisi, C. E., Colburn, W. A., Kaiko, R. F., Houde, R. W., and Foley, K. M. (1987). Pharmacokinetics and pharmacodynamics of methadone in patients with chronic pain. Clin. Pharmacol. Ther. 41, 392-401. doi: 10.1038/clpt.1987.47

Inturrisi, C. E., Portenoy, R. K., Max, M. B., Colburn, W. A., and Foley, K. M. (1990). Pharmacokinetic-pharmacodynamic relationships of methadone infusions in patients with cancer pain. Clin. Pharmacol. Ther. 47, 565-577. doi: 10.1038/clpt.1990.77

Kashuba, A. D., Nafziger, A. N., Kearns, G. L., Leeder, J. S., Shirey, C. S., Gotschall, R., et al. (1998). Quantification of intraindividual variability and the influence of menstrual cycle phase on CYP2D6 activity as measured by dextromethorphan phenotyping. Pharmacogenetics 8, 403-410. doi: 10.1097/00008571-199810000-00005

Kennedy, A. P., Epstein, D. H., Phillips, K. A., and Preston, K. L. (2013). Sex differences in cocaine/heroin users: drug-use triggers and craving in daily life. Drug Alcohol Depend. 132, 29-37. doi: 10.1016/j.drugalcdep.2012. 12.025

Labbé, L., Sirois, C., Pilote, S., Arseneault, M., Robitaille, N. M., Turgeon, J., et al. (2000). Effect of gender, sex hormones, time variables and physiological urinary $\mathrm{pH}$ on apparent CYP2D6 activity as assessed by metabolic ratios of marker substrates. Pharmacogenetics 10, 425-438. doi: 10.1097/00008571-20000700000006

Lamba, J., Strom, S., Venkataramanan, R., Thummel, K. E., Lin, Y. S., Liu, W., et al. (2006). MDR1 genotype is associated with hepatic cytochrome P450 3A4 basal and induction phenotype. Clin. Pharmacol. Ther. 79, 325-338. doi: 10.1016/j.clpt.2005.11.013

Lamba, V., Lamba, J., Yasuda, K., Strom, S., Davila, J., Hancock, M. L., et al. (2003). Hepatic CYP2B6 expression: gender and ethnic differences and relationship to CYP2B6 genotype and CAR (constitutive androstane receptor) expression. J. Pharmacol. Exp. Ther. 307, 906-922. doi: 10.1124/jpet.103. 054866

Li, Y., Kantelip, J. P., Gerritsen-van Schieveen, P., and Davani, S. (2008). Interindividual variability of methadone response: impact of genetic polymorphism. Mol. Diagn. Ther. 8, 109-124. doi: 10.1007/BF03256276

Lynch, W. J., Roth, M. E., and Carroll, M. E. (2002). Biological basis of sex differences in drug abuse: preclinical and clinical studies. Psychopharmacology (Berl). 164, 121-137. doi: 10.1007/s00213-002-1183-2

Maremmani, I., Pacini, M., Cesaroni, C., Lovrecic, M., Perugi, G., and Tagliamonte, A. (2005). QTc interval prolongation in patients on longterm methadone maintenance therapy. Eur. Addict. Res. 11, 44-49. doi: $10.1159 / 000081416$

Martinotti, G., Corazza, O., Achab, S., Demetrovics, Z. (2014). Novel psychoactive substances and behavioral addictions. Biomed. Res. Int. 2014, 534523. doi: $10.1155 / 2014 / 534523$

Mitchell, T. B., Dyer, K. R., Newcombe, D., Salter, A., Somogyi, A. A., Bochner, F., et al. (2004). Subjective and physiological responses among racemicmethadone maintenance patients in relation to relative (S)- vs. (R)-methadone exposure. Br. J. Clin. Pharmacol. 58, 609-617. doi: 10.1111/j.1365-2125.2004. 02221.x

NIDA. (2014). National Institute on Drug Abuse. Available at: http://www. drugabuse.gov/publications/finder/t/162/ResearchReports?page $\$=\$ 1$

Niv, N., and Hser, Y. I. (2007). Women-only and mixed-gender drug abuse treatment programs: service needs, utilization and outcomes. Drug Alcohol Depend. 87, 194-201. doi: 10.1016/j.drugalcdep.2006.08.017

NSDUH. (2010). Substance Abuse, and Mental Health Services Administration. Results from the 2009 National Survey on Drug Use and Health: Volume I. Summary of National Findings (Office of Applied Studies, NSDUH Series H-38A, HHS Publication No. SMA 10-4586 Findings), Rockville, MD.

Pearson, E. C., and Woosley, R. L. (2005). QT prolongation and torsades de pointes among methadone users: reports to the FDA spontaneous reporting system. Pharmacoepidemiol. Drug Saf. 14, 747-753. doi: 10.1002/pd s.1112

Peles, E., and Adelson, M. (2006). Gender differences and pregnant women in a methadone maintenance treatment (MMT) clinic. J. Addict. Dis. 25, 39-45. doi: 10.1300/J069v25n02_06

Pérez de Los Cobos, J., Trujols, J., Valderrama, J. C., Valero, S., and Puig, T. (2005). Patient perspectives on methadone maintenance treatment in the Valencia Region: dose adjustment, participation in dosage regulation, and satisfaction with treatment. Drug Alcohol Depend. 79, 405-412. doi: 10.1016/j.drugalcdep.2005.03.021

Poggio, E. D., Rule, A. D., Tanchanco, R., Arrigain, S., Butler, R. S., Srinivas, T. et al. (2009). Demographic and clinical characteristics associated with glomerular filtration rates in living kidney donors. Kidney Int. 75, 1079-1087. doi: 10.1038/ki.2009.11

Preston, K. L., Epstein, D. H., Davoudzadeh, D., and Huestis, M. A. (2003). Methadone and metabolite urine concentrations in patients maintained on methadone. J. Anal. Toxicol. 27, 332-341. doi: 10.1093/jat/27. 6.332

Rostami-Hodjegan, A., Wolff, K., Hay, A. W., Raistrick, D., Calvert, R., and Tucker, G. T. (1999). Population pharmacokinetics of methadone in opiate users: characterization of time-dependent changes. Br. J. Clin. Pharmacol. 48, 43-52. doi: 10.1046/j.1365-2125.1999.00974.x

Roy, E., Boivin, J. F., and Leclerc, P. (2011). Initiation to drug injection among street youth: a gender-based analysis. Drug Alcohol Depend. 114, 49-54. doi: 10.1016/j.drugalcdep.2010.09.003

Sara, G., Burgess, P., Malhi, G. S., Whiteford, H., and Hall, W. (2013). Differences in associations between cannabis and stimulant disorders in first admission psychosis. Schizophr. Res. 147, 216-222. doi: 10.1016/j.schres.2013.04.017 
Schifano, F., Deluca, P., Agosti, L., Martinotti, G., Corkery, J. M., Alex, B., et al. (2005). New trends in the cyber and street market of recreational drugs? The case of 2C-T-7 ('Blue Mystic'). J. Psychopharmacol. 19, 675-679. doi: $10.1177 / 0269881105056660$

Schuetz, E. G., Furuya, K. N., and Schuetz, J. D. (1995). Interindividual variation in expression of P-glycoprotein in normal human liver and secondary hepatic neoplasms. J. Pharmacol. Exp. Ther. 275, 1011-1018.

Schuetz, E. G., Umbenhauer, D. R., Yasuda, K., Brimer, C., Nguyen, L., Relling, M. V., et al. (2000). Altered expression of hepatic cytochromes P-450 in mice deficient in one or more mdr1 genes. Mol. Pharmacol. 57, 188-197.

Shand, F. L., Degenhardt, L., Slade, T., and Nelson, E. C. (2011). Sex differences amongst dependent heroin users: histories, clinical characteristics and predictors of other substance dependence. Addict. Behav. 36, 27-36. doi: 10.1016/j.addbeh.2010.08.008

Shiran, M. R., Chowdry, J., Rostami-Hodjegan, A., Ellis, S. W., Lennard, M. S., Iqbal, M. Z., et al. (2003). A discordance between cytochrome P450 2D6 genotype and phenotype in patients undergoing methadone maintenance treatment. Br. J. Clin. Pharmacol. 56, 220-224. doi: 10.1046/j.1365-2125.2003.01851.x

Shiran, M. R., Lennard, M. S., Iqbal, M. Z., Lagundoye, O., Seivewright, N., Tucker, G. T., et al. (2009). Contribution of the activities of CYP3A, CYP2D6, CYP1A2 and other potential covariates to the disposition of methadone in patients undergoing methadone maintenance treatment. Br. J. Clin. Pharmacol. 67, 29-37. doi: 10.1111/j.1365-2125.2008.03312.x

Simoni-Wastila, L., Ritter, G., and Strickler, G. (2004). Gender and other factors associated with the non-medical use of abusable prescription drugs. Subst. Use Misuse. 39, 1-23. doi: 10.1081/JA-120027764

Simpson, D. D., Joe, G. W., and Rowan-Szal, G. A. (1997). Drug abuse treatment retention and process effects on follow-up outcomes. Drug Alcohol Depend. 47, 227-235. doi: 10.1016/S0376-8716(97)00099-9

Smith, Y. R., Stohler, C. S., Nichols, T. E., Bueller, J. A., Koeppe, R. A., and Zubieta, J. K. (2006). Pronociceptive and antinociceptive effects of estradiol through endogenous opioid neurotransmission in women. J. Neurosci. 26, 5777-5785. doi: 10.1523/JNEUROSCI.5223-05.2006

Smith, Y. R., Zubieta, J. K., del Carmen, M. G., Dannals, R. F., Ravert, H. T., Zacur, H. A., et al. (1998). Brain opioid receptor measurements by positron emission tomography in normal cycling women: relationship to luteinizing hormone pulsatility and gonadal steroid hormones. J. Clin. Endocrinol. Metab. 83, 4498-4505. doi: 10.1210/jc.83.12.4498

Tamminga, W. J., Wemer, J., Oosterhuis, B., de Zeeuw, R. A., de Leij, L. F., and Jonkman, J. H. (2001). The prevalence of CYP2D6 and CYP2C19 genotypes in a population of healthy Dutch volunteers. Eur. J. Clin. Pharmacol. 57, 717-722. doi: $10.1007 / \mathrm{s} 002280100359$
Tetrault, J. M., Desai, R. A., Becker, W. C., Fiellin, D. A., Concato J., and Sullivan, L. E. (2008). Gender and non-medical use of prescription opioids: results from a national US survey. Addiction 103, 258-268. doi: 10.1111/j.13600443.2007.02056.x

U.S. Food and Drug Administration. (1993). Guideline for the study and evaluation of gender differences in the clinical evaluation of drugs; notice. Fed. Regist. 58, 39406-39416.

Vazquez, V., Gury, C., and Laqueille, X. (2006). Methadone: from pharmacokinetic profile to clinical pharmacology. Encephale 32, 478-486. doi: 10.1016/S00137006(06)76190-5

Wolbold, R., Klein, K., Burk, O., Nüssler, A. K., Neuhaus, P., Eichelbaum, M., et al. (2003). Sex is a major determinant of CYP3A4 expression in human liver. Hepatology 38, 978-988. doi: 10.1053/jhep.2003.50393

Wolff, K., Rostami-Hodjegan, A., Hay, A. W., Raistrick, D., and Tucker, G. (2000). Population-based pharmacokinetic approach for methadone monitoring of opiate addicts: potential clinical utility. Addiction 95, 1771-1783. doi: 10.1046/j.1360-0443.2000.951217717.x

Wolff, K., Rostami-Hodjegan, A., Shires, S., Hay, A. W., Feely, M., Calvert, R., et al. (1997). The pharmacokinetics of methadone in healthy subjects and opiate users. Br. J. Clin. Pharmacol. 44, 325-334. doi: 10.1046/j.1365-2125.1997.t01-100591.x

Wu, D., Otton, S. V., Sproule, B. A., Busto, U., Inaba, T., Kalow, W., et al. (1993). Inhibition of human cytochrome P450 2D6 (CYP2D6) by methadone. Br. J. Clin. Pharmacol. 35, 30-34. doi: 10.1111/j.1365-2125.1993.tb05666.x

Xie, H. G., Kim, R. B., Wood, A. J., and Stein, C. M. (2001). Molecular basis of ethnic differences in drug disposition and response. Annu. Rev. Pharmacol. Toxicol. 41, 815-850. doi: 10.1146/annurev.pharmtox.41.1.815

Zubieta, J. K., Dannals, R. F., and Frost, J. J. (1999). Gender and age influences on human brain mu-opioid receptor binding measured by PET. Am. J. Psychiatry 156, 842-848. doi: 10.1176/ajp.156.6.842

Conflict of Interest Statement: The associate editor, Cesare Mancuso declares that, despite having collaborated with the author Robert Nisticò, the review process was handled objectively. The authors declare that the research was conducted in the absence of any commercial or financial relationships that could be construed as a potential conflict of interest.

Copyright (c) 2015 Graziani and Nisticò. This is an open-access article distributed under the terms of the Creative Commons Attribution License (CC BY). The use, distribution or reproduction in other forums is permitted, provided the original author(s) or licensor are credited and that the original publication in this journal is cited, in accordance with accepted academic practice. No use, distribution or reproduction is permitted which does not comply with these terms. 